\title{
Updating the range of problems within legal risks in healthcare through the analysis of judicial practice
}

\author{
Maksim Gennadievich Sveredyuk ${ }^{1^{*}}$ \\ ${ }^{1}$ Regional State Budgetary Educational Institution of Additional Professional Education "Institute for \\ Advanced Training of Healthcare Professionals", Department of Health Organization and Medical \\ Law, Khabarovsk, Russia
}

\begin{abstract}
The identification and assessment of risk factors are facilitated by law administration and enforcement. Decisions of the judicial authorities constitute one of the directions. In this regard, first, the analysis and generalization of judicial practice show the range of problems of various aspects of activities, and second, it allows forming a model of suppressing or minimizing legal risks. Sociological research conducted from 2008 to 2020 by the Department of Healthcare Organization and Medical Law of the Regional State Budgetary Educational Institution of Additional Professional Education "Institute for Advanced Training of Healthcare Professionals" (Khabarovsk) revealed that these specialists had no idea about the number of litigations in so-called "medical cases", or about the amounts recovered on claims of patients to medical organizations of the Khabarovsk Territory. Meanwhile, having information on the quantitative and summary indicators of court cases, it is possible to adjust interaction with patients at both pretrial and trial stages. The study aimed to analyze and summarize judicial practice in these cases, to selectively examine defects that served as the basis for filing claims and had an impact on the amounts recovered, as well as to form practical recommendations for the prevention of legal risks in the activities of a medical organization, based on a regional model. The relevance of the problem of legal risks of medical activity is shown from the standpoint of analysis and generalization of judicial practice. The article provides a statistical analysis of court proceedings on claims of patients for compensation for material damage and moral harm to medical organizations subordinate to the Ministry of Health of the Khabarovsk Territory. A selective examination of the claims of patients is executed considering the impact on the reasons for legal recourse and the total amount recovered. Practical recommendations for regional healthcare institutions are annually formed and approved by the Minister of Health of the Khabarovsk Territory based on the results of the study.
\end{abstract}

Keywords: legal risk, compensation of damage, judicial practice, a patient, statement of claim, healthcare legislation

\footnotetext{
*Corresponding author: uristms27@bk.ru
} 


\section{Introduction}

In modern science, the concept of a "risk society" [1] is put forward, which can be expressed by the "there is no risk-free behavior" phrase [2]. "In other words, risks are manifested at all levels of the functioning of the social system" [3]. The issues of identifying risks in legal activities are gaining more and more practical importance. Magaziner pointed out that "the law is nothing but a system of distribution of risks, which changes and corrects the spontaneously emerging distribution of risks based on the natural laws of the economy" [4]. Legal risks are relevant for all areas of public relations. The sphere of health protection, and medical activity, in particular, is no exception. As rightly noted by Professor W. Osler, "Medicine is the science of uncertainty and the art of probability" [5]. Rigelman believes that uncertainty in medicine cannot be eliminated. "The main thing is to learn to recognize the existence of uncertainty and skillfully share doubts with the patient" [6].

Risk has been poorly researched in the medicine area. The existing legislation in the field of healthcare discloses neither the concept of medical risk nor the conditions for its justification. This makes it difficult to assess the activities of medical workers in the risky situations allowed by them [7]. The concept of medical risk is very broad, covering the entire sphere of organization and functioning of the health care system, and includes various kinds of risks: medical and financial, medical and economic, medical and technical, risks of defects in medical activities, etc.

The primary task is to see the range of problems and to analyze the factors underlying the risk phenomena.

\section{Results}

One of the components of prevention and mitigation of legal risks is a systematic analysis and generalization of judicial practice on claims of patients to medical organizations, including those in such a category of cases as the recovery of financial and (or) moral damage. Such work has been carried out systematically in the Khabarovsk Territory starting in 2018 when the first study was carried out by the Regional Ministry of Health and the Department of Health Organization and Medical Law of the Institute for Advanced Training of Healthcare Professionals [8].

As a result of the analysis it was established that for 10 months of 2018, in quantitative terms, patients (representatives) filed 111 claims. The total amount of claims of patients (legal representatives) amounted to 230.021 million rubles. (claims were made for 2.072 million rubles on average).

The total amount of claims satisfied by the courts based on the results of 44 cases considered, in which the decisions of the courts entered into legal force, amounted to 12.162 million rubles (on average, claims were satisfied for 276.427 thousand rubles). For comparison, the average amount of satisfied claims in this segment in Moscow was 213.561 thousand rubles [9].

The maximum amount of satisfied claims for moral damage compensation amounted to 2.5 million rubles and 242.155 thousand rubles for material damage (the cost of operating).

An examination of reasons both for claim submission and for the decision of the court on the amount of the recovery was carried out for some cases. In addition to defects in the provision of medical care, the following factors influencing the final amount of recovery were identified: ignoring the patient's claim, not conducting a proper pre-trial examination of medical documentation, lack of clear position on the actual circumstances of the case, not knowing the risks of applying penalties under consumer protection legislation.

So, in case No. 2-308/2018, considered by the Zheleznodorozhny District Court of the city of Khabarovsk, an amount of more than twice the patient's requirements was recovered. 
The main medical and legal defect on the part of the medical organization was the disregard of the patient's written claim. The decision of the court says: "given that the pre-trial claim of the plaintiff came to the defendant, they should have satisfied it or should have provided an answer to it". Exclusively in this regard, taking into account the forfeit and the fine, the court awarded the amount of 849765 rubles 38 kopecks, which more than doubled the claims of the plaintiff.

An important aspect in litigation in this category of cases is the relationship between a lawyer and a medical professional. It is the lawyer who can develop the tactics and strategy of the process if he possesses objective information about the presence or absence of defects. There are situations when it is advisable to conclude an amicable agreement in a court proceeding that has already begun. Concerning this situation, case No. 2-593/2018, considered by the Central District Court of the city of Khabarovsk, can be cited. As a result of poorly provided medical care by the defendant, the plaintiff and her husband lost their child. The plaintiff gave birth to a still child for about 9 hours, experiencing severe mental suffering in addition to physical pain. According to the results of the examination, defects in the provision of medical care were identified. Besides, as a result of a poor-quality ultrasound scan after childbirth, the plaintiff has not had the remnants of the placenta removed, which while decomposing, could have led to the death of the plaintiff, and therefore she again had to experience physical pain and mental suffering during bleeding and curettage of the uterine cavity. The plaintiff asked the court to recover from the defendant Regional Governmentowned Publicly Funded Health Care Institution the monetary compensation for moral damage for 2.0 million rubles. At the hearing, the defendant's representatives offered to conclude an amicable agreement with the plaintiff. As a result, according to the amicable agreement approved by the court, the Regional Government-owned Publicly Funded Health Care Institution undertakes to pay the plaintiff the compensation for moral damage for 300.0 thousand rubles.

The increase in the total of the amounts recovered, as a rule, depends on the presence of medical defects precisely. Meanwhile, significant amounts are sometimes recovered for organizational defects.

Case No. 2-662/2017, considered by the Industrial District Court of the city of Khabarovsk, can be mentioned as an example:

On the fourth day after the birth of the plaintiff's child, blood was taken on a test form of the established sample for analysis. As it turned out later, the child's blood was not taken, the analysis was not carried out, but the negative result of no hereditary diseases was reflected, which misled the parents and medical workers, as a result of which they did not start timely high-quality treatment for the child. Later, the child was diagnosed with phenylketonuria. The disease should have been detected during the first examination of the child's blood. The child was assigned the "Disabled child" disability group. Having considered the claims for the recovery of compensation for moral damage, the court came to the following conclusions: when determining the amount of compensation for moral damage to be recovered in favor of the plaintiff, the court takes into account that the harm caused to her was not the result of intentional criminal acts, although undoubtedly the plaintiff suffered emotional distress. Therefore, the amount of compensation for moral damage is to be reduced from 6 million rubles to 1 million rubles in favor of the child, and 1.5 million rubles in favor of the mother.

\section{Discussion}

The analysis of judicial practice shows the pressure points of legal relations in the implementation of medical activities. In this regard, it is relevant to talk about the need to build a legal risk management system for the activities of a medical organization. Risk 
management is the impact on risk or risks leading to a change in one or more characteristics of risk, i.e. probability and (or) consequences [10].

For the healthcare sector, risk control and risk management are also relevant, as evidenced by the fact that these terms are enshrined in the "Specialist in the field of healthcare and public health" professional standard (Order of the Ministry of Labor of Russia dated November 07, 2017, No. 768n "On the approval of the "Specialist in the field of healthcare and public health" professional standard).

Risk management is an extremely complex, comprehensive phenomenon, which is advisable to be considered as a system [11].

For a holistic perception of the system, it is necessary to determine the methods of influencing the risks to minimize possible damage in the future, as well as the stages of risk management. There are 3 main methods: risk reduction; preservation of risk; transfer and distribution of risk [12].

While investigating the question of staging the risk management process, it is necessary to single out the following universal risk management stages [13-15], without which the studied risk management system cannot function: risk identification, risk assessment, risk response, monitoring and revision of the management system risks.

It can be said that the risk management system, including medical and legal risks, is a constant self-analysis to adjust the content of the system structure to minimize risk factors.

Taking this analysis into account, it seems that the medical and legal risk management system at the local level may consist of the following subsystems:

- improvement of internal quality control and safety of medical activities (organization of the medical commission work, introduction of clinical audit, control over the proper maintenance of medical records);

- formation of local mechanisms for the implementation of legal norms;

- increasing the legal knowledge of medical workers; monitoring the psycho-emotional factors that affect the legal consciousness of medical workers to prevent legal nihilism.

The inclusion of these aspects in the legal risk management system will significantly minimize the factors of influence and improve the quality of medical activities.

\section{Conclusion}

Legal risks permeate all aspects of public relations. One of the main tasks should be the task of their prevention and minimization. The problem is especially acute in legal relations affecting the most important human rights - the right to life and the right to health. The identification of risk factors is facilitated by various studies: sociological, statistical, comparative. Undoubtedly, one of the most effective is the analysis and generalization of judicial practice since these studies allow establishing the subject of the problem and the factors contributing to its occurrence. The logical conclusion of a systematic study of judicial practice should be the formation of a legal risk management system and its introduction into the activities of a medical organization.

Measures should be planned and implemented in the plans of medical institutions and programs for the development of health authorities at all levels annually to prevent risk phenomena, including medical and legal risks. It is recommended to ensure that risk events are monitored starting from the hospital level up to the federal healthcare management level.

The formation of a risk management system, its implementation, and monitoring will allow solving a whole range of problems, including the medical care availability and quality. 


\section{References}

1. U. Beck, World at Risk (Cambridge: Polity Press, 2010)

2. N. Luhman, Almanac "THESIS" 5, 135-160 (1994)

3. O. P. Bessmertnaya and N.G. Bondarenko, Econ. and Human. Research of Reg. 4 (2016)

4. A.Y. Bushev, Arbitration Disputes 3 (2008)

5. W. Osler, The principles and practice of medicine (1925)

6. Oboronitelnaya meditsina [Defensive medicine]. Accessed on: April 07, 2021. [Online]. Available: http://lib.komarovskiy.net/oboronitelnaya-medicina-defensivemedicine.html

7. N.S. Kozaev, Ugolovno-pravovye aspekty meditsinskogo riska [Criminal and legal aspects of medical risk] in Proc. "Society - Medicine - Law" First Int. Conf. (Kislovodsk, May 1999)

8. Analiz i obobshchenie sudebnoi praktiki po iskam patsientov o vozmeshchenii materialnogo ushcherba i moralnogo vreda k meditsinskim organizatsiyam, podvedomstvennym Ministerstvu zdravookhraneniya Khabarovskogo kraya, za 2018 god [Analysis and generalization of judicial practice on claims of patients for compensation for material damage and moral harm to medical organizations subordinate to the Ministry of Health of the Khabarovsk Territory for 2018] (Khabarovsk: Printing and publications center IPKSZ, 2019)

9. Y.V. Sidorovich, Ekspertiza nedostatkov okazaniya meditsinskoi pomoshchi po grazhdanskim delam: prognozirovanie riskov dlya meditsinskikh organizatsii [Examination of defects in medical care in civil cases: risk prediction for medical organizations] in Proc. Sci. and Pract. Conf. "Actual problems of medical law in Russia" (St. Petersburg, June 01-03, 2018)

10. A. Shishakov, Corporate Lawyer 7, 46-48 (2008)

11. Novaya filosofskaya entsiklopediya [New philosophy encyclopedia]. Accessed on: April 07, 2021. [Online]. Available:

https://iphlib.ru/library/collection/newphilenc/page/about

12. G. Duttge and S.W. Lee, The Law in the Information and Risk Society (Gottingen. 2011)

13. Risk management - Vocabulary - Guidelines for use in standards, "ConsultantPlus" legal reference system

14. UN Global Compact. A Guide for Anti-Corruption Risk Assessment. (New York, 2013)

15. A Risk Management Standard (London, 2002) 